\title{
COVID-19'S Impact on Brand, Campaigning and Marketing Creativity: A Social Marketing Theoretical Approach
}

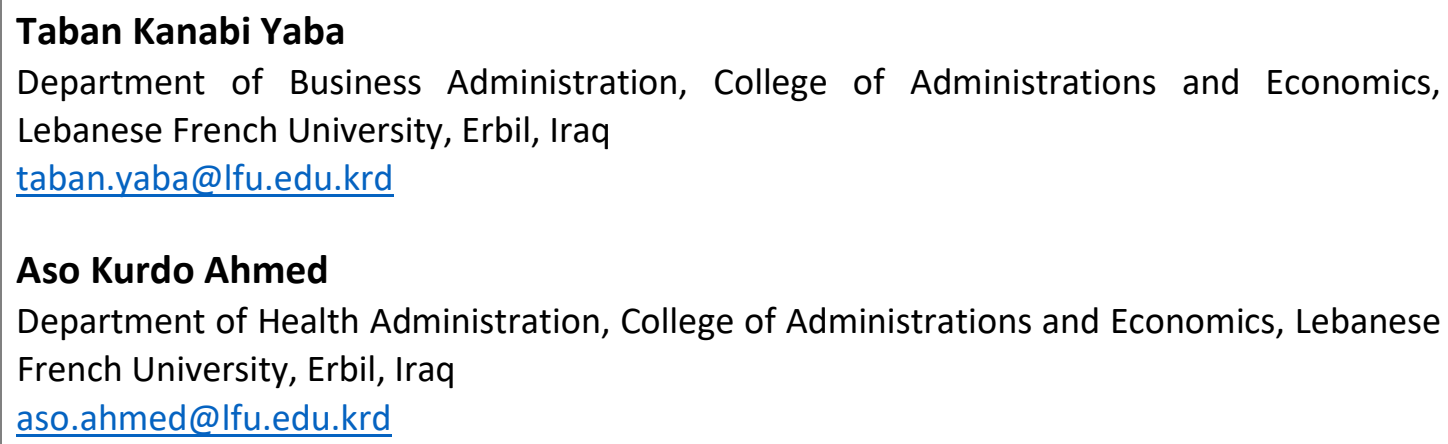

Department of Business Administration, College of Administrations and Economics, Lebanese French University, Erbil, Iraq

taban.yaba@Ifu.edu.krd

\section{Aso Kurdo Ahmed}

Department of Health Administration, College of Administrations and Economics, Lebanese French University, Erbil, Iraq

aso.ahmed@Ifu.edu.krd

\section{Karzan Qader Hamad}

Department of Tourism Administration, College of Administrations and Economics, Lebanese French University, Erbil, Iraq

karzan.ahmed@lfu.edu.krd

\section{ARTICLE INFO}

\section{Article History:}

Received: 12/8/2021

Accepted: 15/9/2021

Published: Autumn 2021

Keywords: Advertising, brands, Covid-19, creativity, marketing

Doi:

10.25212/Ifu.qzj.6.4.33

ABSTRACT
Covid-19's impact on brands, creativity and marketing have
been neglected as studies are being drawn on broader
business and economic aspects. The research explores Covid-
19's impact on brands, creativity and marketing using a
qualitative approach. The social marketing theoryand related
empirical applications were applied to find future areas of
applications and establish sound basis upon which provide
practical strategies needed to enhance financial and
organizational performance were provided. Established
findings depicted that shows that when the pandemic hit,
consumers were moving their focus from the top pyramid
(self-actualization and esteem) to the bottom (belonging and
safety needs) of Maslow's hierarchy of needs. The findings
revealed that the SMT's collective theoretical ideas suggest
that it is vital for companies to promote valuable information
during and after Covid-19 using creative branding, advertising
and marketing strategies to enhance their financial and
944




\section{QALAAI ZANISTSCIENTIFIC JOURNAL \\ A Scientific Quarterly Refereed Journal Issued by Lebanese French University - Erbil, Kurdistan, Iraq \\ Vol. (6), No (4), Autumn 2021 \\ ISSN 2518-6566 (Online) - ISSN 2518-6558 (Print)}

organizational performance. Illustrations made using the SMT depict the importance of targeting the right audience at a time when Covid-19 has altered consumers' behavior, tastes and preferences. The Research recommends that creative, practical and innovative branding, marketing and advertising approaches be devised to create audience awareness, target the right audience, reinforce messages, cultivate impressions or images, stimulate interests and induce desired results for firms to enhance their financial and organizational performance during the Covid-19 era. Such forms a sound theoretical and practical base on which the present research's contributions and novelty are centered.

\section{INTRODUCTION}

The Corona virus has posed huge negative effects on all occupations with its effects having various social, religious and economic effects. The prevalence of the Corona virus also known as Covid-19 has altered social and economic activities coupled by restrictions in gathering, social distancing, quarantines the use of face masks and sanitizers to curb the spreading of the pandemic (Meyer, Prescott \& Sheng, 2021, p.2). Various businesses scaled their operations (Seetharaman, 2020) while others resorted to online platforms to conduct their operations just to stay afloat in business (Manlova, Brush \& Edelman, 2020, p. 484). Researchers have devoted significant attention towards exploring Covid-19's effects on broader economic aspects (Batik et al., 2020; Fairlie, 2020; Hasanat et al., 2020), but little has been done to explore similar effects on branding and marketing activities, their resultant effects on creativity and how organizations should organize themselves to benefit from these observed innovative changes caused by Covid-19.

One can undeniably argue that the emergence and increased prevalence of Covid-19 has instituted numerous changes, which do not spare brands, creativity and marketing activities and platforms. Consequently, this research's primary purpose is to explore Covid-19's impact on brands, creativity and marketing. Such will be attained by employing a qualitative approach to answering the following questions; 


\section{QALAAI ZANISTSCIENTIFIC JOURNAL \\ A Scientific Quarterly Refereed Journal Issued by Lebanese French University - Erbil, Kurdistan, Iraq \\ Vol. (6), No (4), Autumn 2021 \\ ISSN 2518-6566 (Online) - ISSN 2518-6558 (Print)}

- In what ways does the social media marketing theory explain the importance of companies adopting creative branding, campaigns and marketing strategies before and during the pandemic?

- Has Covid-19 changed consumers' needs and wants before and during the pandemic?

Ideas provided in this research provide a platform on which the validity of social media marketing theories is put to test in the midst of structural imbalances like Covid-19. Contemporary branding and marketing strategies are also provided at a time were various social, economic, religious, political activities have increasingly adopted innovative electronic platforms to hedge against Covid-19's effects. Hence, this present study provides distinct and sound theoretical and empirical implications vital for enhancing the innovative development and effective use of branding, advertising and marketing platforms and strategies capable of enhancing financial and organizational performance.

\section{LITERATURE REVIEW}

The social marketing theory (SMT) provides relevant information and ideas indicating how Covid-19 has initiated creativity and impacted branding and marketing activities. The SMT is an attempt to clearly understand how societal and psychological factors work to successfully manipulate them in order to increase how effective mass media information campaigns are (Dann, 2010; Wood, 2012). Sharp (2017) highlights that the SMT uses collective theoretical ideas to depict how to valuably promote information.

Restrictions in various public activities and various adversities posed by social distancing have limited the extent and nature of information accessed by customers. Such follows a decline in traditional shopping strategies (Hastings \& Saren, 2003). McDermott, Stead and Hastings (2005) contends that customers highly prefer in-store activities compared to online shopping and hence, Covid-19 is seen as hampering window shopping (Fairlie, 2020) and word-of-mouth (Manolova, et al., 2020, p.4.51). Such place organizations under pressure to devise creative ways of reaching 


\section{QALAAI ZANISTSCIENTIFIC JOURNAL \\ A Scientific Quarterly Refereed Journal Issued by Lebanese French University - Erbil, Kurdistan, Iraq \\ Vol. (6), No (4), Autumn 2021 \\ ISSN 2518-6566 (Online) - ISSN 2518-6558 (Print)}

customers and brand their products and service to innovatively appeal to customers who have resorted to online platforms for e-shopping and other online activities.

The SMT compels organizations to adopt innovative ways of disbursing information to customers (Wood, 2008). Such is essential when traditional shopping and in-store activities have been adversely affected by Covid-19. Thus, efforts consumers' Covid19 responsive behavior and ideas need to be captured as postulated by the SMT (Wood, 2012). The SMT also depicts the importance of targeting the right audience at a time when Covid-19 has altered consumers' behavior, tastes and preferences (Dann, 2010; Hastings \& Saren, 2003; Wood, 2012). Furthermore, the SMT denotes the importance of organizations to adopt creative ways to brand, market and advertise their products and services to target the right audience (Sharp, 2017). A study by McDermott, Stead and Hastings (2005) contends that creative ways are needed to reinforce advertised messages and such can be accomplished using ideas provided by the SMT (Hastings \& Saren, 2003). Challenges posed by Covid-19 demand creative branding, marketing and advertising strategies to cultivate images or impressions (Dann, 2010. P. 149). However, this requires creative branding and marketing strategies capable of stimulating consumers' interest. This is crucial for inducing desired results leading to improved financial and organizational performance. Thus, the SMT offers a platform upon which organizations can develop practical strategies to enhance their creativity towards developing effective branding and marketing strategies that can hedge firms against the adverse effects of Covid19. Such needs to be done on the premise of good and creative branding, and marketing strategies capable of creating audience awareness, targeting the right audience, reinforcing messages, cultivating impressions or images, stimulating interests and inducing desired results.

\section{METHODOLOGY}

The research uses applications scientific approach to explore Covid-19's impact on brands, creativity and marketing. This is because qualitative research allows organizations to understand consumers' attitudes (Pathak, Jena \& Kalra, 2013). Consumer patterns have changed since the emergence and prevalence of Covid-19 


\section{QALAAI ZANISTSCIENTIFIC JOURNAL \\ A Scientific Quarterly Refereed Journal Issued by Lebanese French University - Erbil, Kurdistan, Iraq \\ Vol. (6), No (4), Autumn 2021 \\ ISSN 2518-6566 (Online) - ISSN 2518-6558 (Print)}

and this imposes challenges on organizations as they are forced to devise new and effective ways to brand and market their products and services. A qualitative research approach serves as a content generator which firms can utilize to find new ways to present old content (Silverman, 2020). Presenting old content during the Covid-19 era can be very difficult, even to an experienced marketer. As a result, the qualitative research approach allows for genuine ideas to be collected from specific socioeconomic demographics. Practical branding, advertising and marketing ideas drawn from worldwide cases to illustrate the extent and nature to which Covid-19 has stimulated creativity, and affected branding and marketing activities. Such was reinforced using ideas provided by the social marketing theory and related empirical studies.

\section{FINDINGS}

Application of the SMT reveal that Covid-19 challenges affecting organizational activities require creative branding and marketing strategies. With swift and stern changes in traditional shopping activities restricting window shopping activities and altering consumers' behavior, needs, tastes and preferences. This can be supported TD Reply's 2020 findings revealing that consumers' need before and during the pandemic have significantly changed (see Figure 1). Figure (1) shows that when the pandemic hit, consumers were moving their focus from the top of the pyramid (selfactualization and esteem) to the bottom (belonging and safety needs).

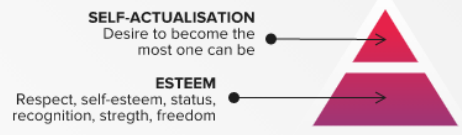

BELONGING Friendship, intimacy, family, ense of connection SAFETY NEEDS Personal security, employment resources, health, property PHYSIOLOGICAL NEEDS Air, water, food,
sleep, clothing 


\section{QALAAI ZANISTSCIENTIFIC JOURNAL \\ A Scientific Quarterly Refereed Journal Issued by Lebanese French University - Erbil, Kurdistan, Iraq \\ Vol. (6), No (4), Autumn 2021 \\ ISSN 2518-6566 (Online) - ISSN 2518-6558 (Print)}

Figure (1): Changes in consumers' needs before and during the pandemic (Source:

TD Reply, 2020)

The information provided in Figure (1) shows the importance of companies improving their brands, adopting creative marketing strategies to successfully benefit from societal and psychological factors responsible for causing a change in consumers' needs before and after the pandemic. As such, it is important for companies to use campaigns that are typically appealed to COVID-19 related messaging. This is in line with propositions made in a previous study by McDermott, Stead and Hastings (2005) highlighting that this can include using emotions in a way that reflect their brand purpose and consumers' needs. Furthermore, consumers tend to resonate with original campaigns and hence, companies must use original and creative COVID-19 campaigns and marketing strategies that resonate with consumers' mind, attitudes, approach and behavior. If not, then the campaign will be ineffective.

It is apparent that traditional shopping methods have been seriously affected by Covid-19, and consumers are increasingly resorting to online or virtual shopping platforms at the comfort of their homes. Thus, SMT propositions established in this study require existing and new companies to creating audience awareness to promote any current and new products, services or ideas. Porter's five forces suggests that costs can hinder a firm's competitiveness (Grundy, 2006, p. 221), and the prevalence of Covid-19 has left many companies struggling to cut down operational costs. Similar propositions were made by Hastings and Saren (2003) revealing that creative branding, campaigns and marketing strategies will target the right audience thereby cutting costs and ensure higher levels of audience penetration. Such is importance at a time when Covid-19 has altered consumers' behavior, tastes and preferences. Besides, Sharp (2017) contends that creative and original campaigns and marketing strategies can reinforce messages, cultivate impressions or images that can Stimulate consumers' interest and induce them to act in a manner that benefits the companies (desired result).

Furthermore, it is crucial for companies to induce desired current and post-Covid-19 results leading to improved financial and organizational performance. In overall, the 


\section{QALAAI ZANISTSCIENTIFIC JOURNAL \\ A Scientific Quarterly Refereed Journal Issued by Lebanese French University - Erbil, Kurdistan, Iraq \\ Vol. (6), No (4), Autumn 2021 \\ ISSN 2518-6566 (Online) - ISSN 2518-6558 (Print)}

research's findings reveal that the SMT offers a platform upon which organizations can develop practical strategies to enhance their creativity towards developing effective branding and marketing strategies that can hedge firms against the adverse effects of Covid-19. Such needs to be done on the premise of good and creative branding, and marketing strategies capable of creating audience awareness, targeting the right audience, reinforcing messages, cultivating impressions or images, stimulating interests and inducing desired results (Wood, 2012).

\section{CONCUSIONS}

Covid-19's effects of branding and marketing are highly evident and just like any economic and social activity, demand creative approaches to address its effects. Thus, firms are able to enhance their financial and organizational performance during the Covid-19 era on the premise that creative, practical and innovative branding, marketing and advertising approaches are devised to create audience awareness, target the right audience, reinforce messages, cultivate impressions or images, stimulate interests and induce desired results. Such forms a sound theoretical and practical base on which the present study's contributions and novelty are centered. These recommendations are essential propositions implied by the social marketing theory and vital for enhancing financial and organizations performance. The SMT is a vital theoretical framework which firms can utilize to clearly understand how societal and psychological factors work during and after the Covid-19 era to successfully manipulate them in order to increase the effectiveness of mass media information campaigns. The SMT's collective theoretical ideas depict how firms can promote valuable information during and after Covid-19 using creative branding, advertising and marketing strategies to enhance their financial and organizational performance. The SMT also depicts the importance of targeting the right audience at a time when Covid-19 has altered consumers' behavior, tastes and preferences.

The recommends companies to use creative and original COVID-19 campaigns and marketing strategies that resonate with consumers' mind, attitudes, approach and behavior to maintain and boost their market share and performance. The study's findings are limited to the theoretical applications and implications of the social 


\section{QALAAI ZANISTSCIENTIFIC JOURNAL \\ A Scientific Quarterly Refereed Journal Issued by Lebanese French University - Erbil, Kurdistan, Iraq \\ Vol. (6), No (4), Autumn 2021 \\ ISSN 2518-6566 (Online) - ISSN 2518-6558 (Print)}

marketing theory. Besides, it is a general approach to the examination of Covid-19's effects on branding and marketing. Future, studies needed to use other theoretical ideas like the technology acceptance model to broaden the study's scope by incorporating insights like consumer perceptions and satisfaction. Such includes conducting surveys and applying quantitative methods to test established Covid-19's campaigns and marketing ideas' validity.

\section{REFERENCES}

Bartik, A. W., Bertrand, M., Cullen, Z., Glaeser, E. L., Luca, M., \& Stanton, C. (2020). The impact of COVID-19 on small business outcomes and expectations. Proceedings of the National Academy of Sciences, 117(30), 17656-17666.

Dann, S. (2010). Redefining social marketing with contemporary commercial marketing definitions. Journal of Business research, 63(2), 147-153.

Fairlie, R. W. (2020). The impact of COVID-19 on small business owners: Continued losses and the partial rebound in May 2020. NBER working paper, (w27462).

Grundy, T. (2006). Rethinking and reinventing Michael Porter's five forces model. Strategic Change, 15(5), 213-229.

Hasanat, M. W., Hoque, A., Shikha, F. A., Anwar, M., Hamid, A. B. A., \& Tat, H. H. (2020). The impact of coronavirus (COVID-19) on e-business in Malaysia. Asian Journal of Multidisciplinary Studies, 3(1), 85-90.

Hastings, G., \& Saren, M. (2003). The critical contribution of social marketing: theory and application. Marketing theory, 3(3), 305-322.

Manolova, T. S., Brush, C. G., Edelman, L. F., \& Elam, A. (2020). Covid19, pivoting to stay the course: How women entrepreneurs take advantage of opportunities created by the COVID-19 pandemic. International Small Business Journal, 38(6), 481-491.

McDermott, L., Stead, M., \& Hastings, G. (2005). What is and what is not social marketing: the challenge of reviewing the evidence. Journal of Marketing Management, 21(5-6), 545-553. 


\section{QALAAI ZANISTSCIENTIFIC JOURNAL \\ A Scientific Quarterly Refereed Journal Issued by Lebanese French University - Erbil, Kurdistan, Iraq \\ Vol. (6), No (4), Autumn 2021 \\ ISSN 2518-6566 (Online) - ISSN 2518-6558 (Print)}

Meyer, B. H., Prescott, B., \& Sheng, X. S. (2021). The impact of the COVID-19 pandemic on business expectations. International Journal of Forecasting.

Pathak, V., Jena, B., \& Kalra, S. (2013). Qualitative research. Perspectives in clinical research, $4(3)$.

Seetharaman, P. (2020). Business models shifts: Impact of Covid-19. International Journal of Information Management, 54, 102173.

Sharp, B. (2017). Marketing: theory, evidence, practice. Oxford University Press,.

Silverman, D. (Ed.). (2020). Qualitative research. Sage Publications Limited.

TD Reply (2020). Covid-19 impact on brands and Creativity. Accessed from https://www.reply.com/en/covid-19-impact-on-brands-and-creativity on 1 March 2021.

Wood, M. (2008). Applying commercial marketing theory to social marketing: A tale of 4Ps (and a B). Social Marketing Quarterly, 14(1), 76-85.

Wood, M. (2012). Marketing social marketing. Journal of Social Marketing.

\section{كاريكهرى كوّقيد- 19 لهسهر داهيّانى براند، كهيين و بهبازارِكردن: نزيكبوونهوهيهكى تيوّرى بوّ بهبازارِكردنى كوّمهلاّيهتى}

كاريگهريى كوّقيد - 19 له سهر براندكان و داهيّنان و بازارِكردن يشتكويِخرا و خويّندن لهسهر بوارى بازركانى وئابوورى به شيوه يه كى فراوانتر. ئةم تويّزينهوهيه كاريكهرى كوّقيد 19 لهسهر براندةكان و داهيّنان و بازارِكردن به بهكارهيِنانى رِيّكَى جوّّنايهتى. تيوّرى ى بازارِكردنى كوّمهلاِيهتى وتاقيكردنهوه ئهزموونكهرييه يهيوهنديدارهكان جيّبهجيّكران بوّ دوّزينهوهى ناوجهكانى ئاينده لهتاقيكردنهوهكان و دامهزراندنى بنهماى دهنكى كهبو دابينكردنى ستراتيزى يراكتيكى ييّويست بوّ 


\section{QALAAI ZANISTSCIENTIFIC JOURNAL}

A Scientific Quarterly Refereed Journal Issued by Lebanese French University - Erbil, Kurdistan, Iraq

Vol. (6), No (4), Autumn 2021

ISSN 2518-6566 (Online) - ISSN 2518-6558 (Print)

يهرهييّدانى ئهداى دارايى و ريّكخراوهيى دهستهبهركرا. دامهزراوه دؤزةرةوةكان ييشانيان دا كه كاتيّك

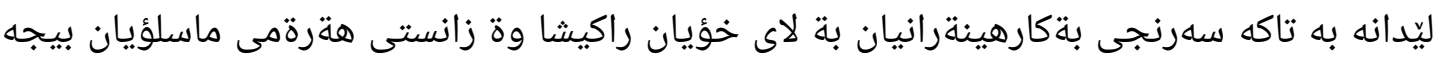

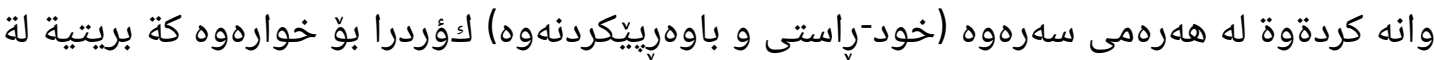

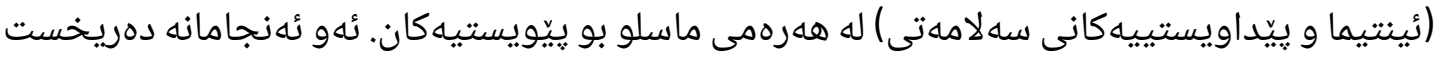

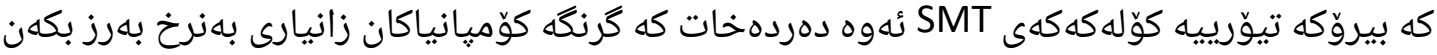
له ماوهى كوّقيد - 19 دا و دواى ئهوهى كه به بهكارهيّنانى براندى داهيّنهرانه و ريكلام و ستراتيزى

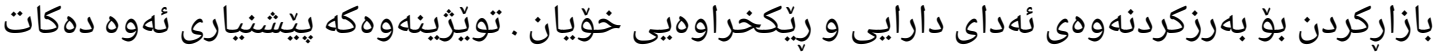

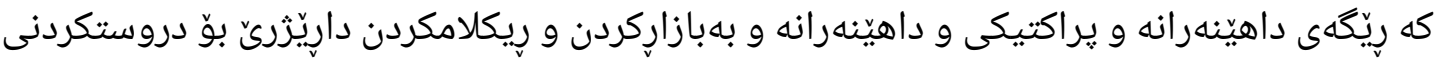

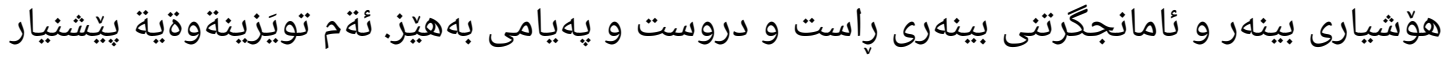

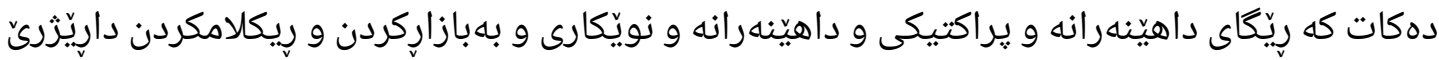

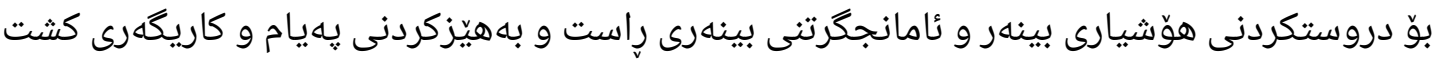

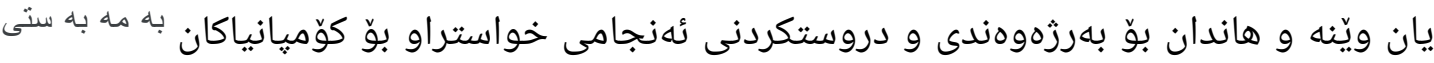

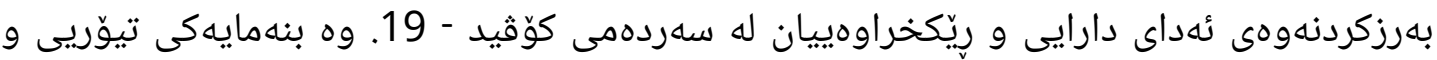

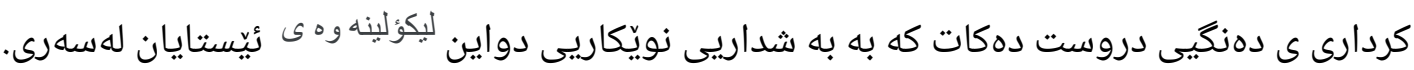

\section{تأثير كوفيد -19 على إبداع العلامة التجارية والحملات والتسويق: نهج نظري للتسويق الاقيق الاجتماعي}

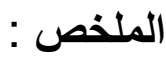

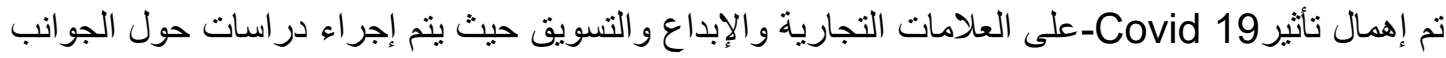

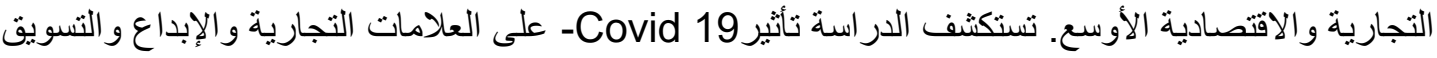

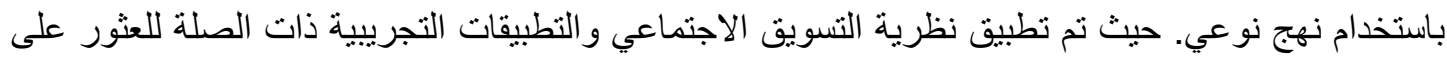

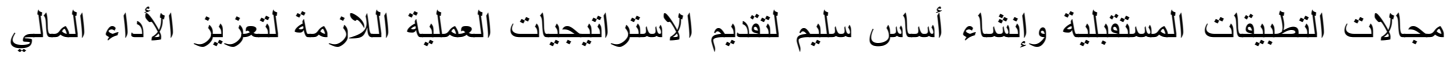

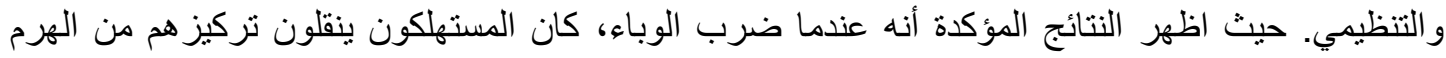

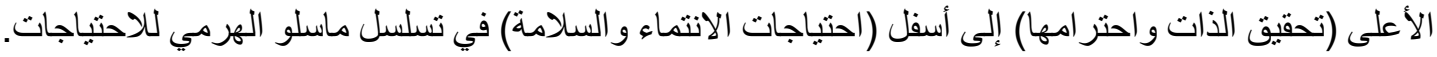

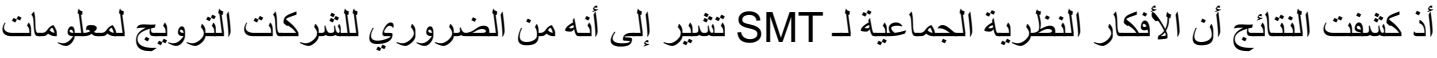

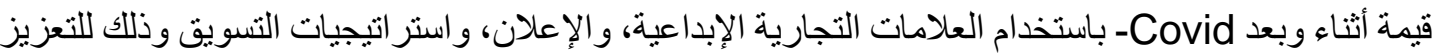




\section{QALAAI ZANISTSCIENTIFIC JOURNAL}

A Scientific Quarterly Refereed Journal Issued by Lebanese French University - Erbil, Kurdistan, Iraq

Vol. (6), No (4), Autumn 2021

ISSN 2518-6566 (Online) - ISSN 2518-6558 (Print)

أدائها المالي و التنظيمي. حيث توضح الرسوم التوضيحية التي تم إجراؤها باستخدام SMT أهمية استهداف

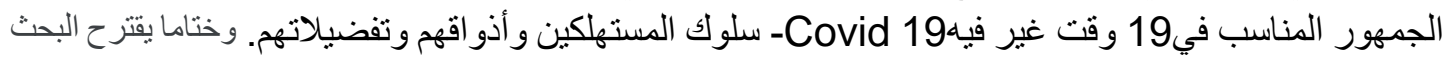

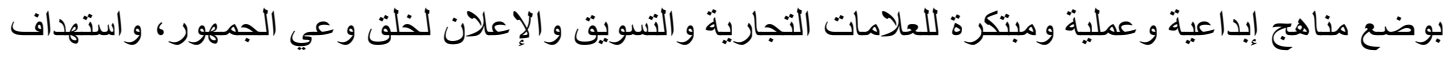

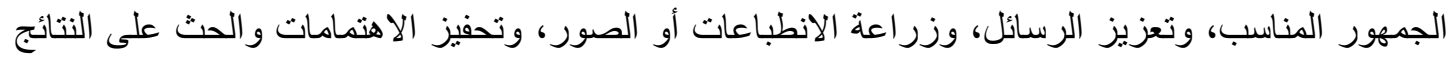

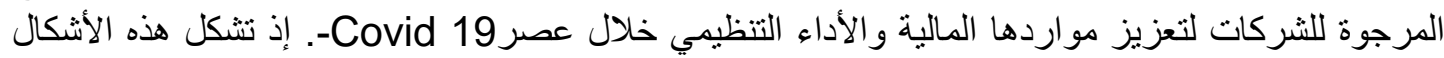

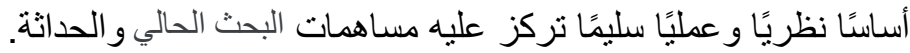

